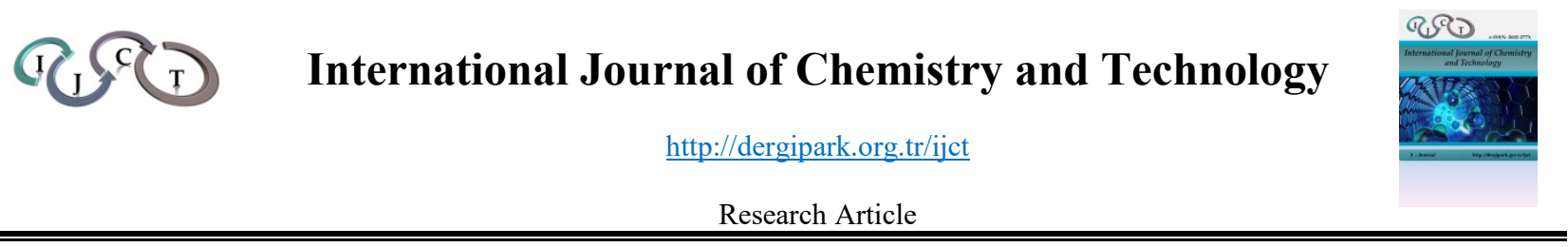

\title{
The role of Lavandula sp. extract for effective inhibiting the mild steel corrosion in the hydrochloric acid solution
}

\author{
Demet ÖZKIR ${ }^{1, *}$ \\ ${ }^{I}$ Niğde Ömer Halisdemir University, Faculty of Arts \& Sciences, Department of Chemistry, Niğde 51240, Turkey
}

Received: 26 May 2021; Revised: 16 July 2021; Accepted: 2 August 2021

*Corresponding author e-mail: dozkir@ohu.edu.tr

Citation: Özkır, D. Int. J. Chem. Technol. 2021, 5 (2), 125-132.

\section{ABSTRACT}

The role of lavender extract in the present study is to examine the effect of inhibiting the corrosion of mild steel in the ambient conditions with its green and eco-friendly effect. It was determined the influence of inhibitor using electrochemical impedance spectroscopy (EIS) in different immersion times. From the EIS measurement results, it was observed that as the concentration of Lavandula extract in the $\mathrm{HCl}$ solution increased, the polarization resistance $\left(R_{p}\right)$ values in the EIS diagram increased. Finally, scanning electron microscope (SEM) analysis was conducted to better clarify the surface inhibition of the electrode containing Lavandula sp. extract at the highest concentration, $0.500 \%(\mathrm{w} / \mathrm{v})$, at the end of the 120 $\mathrm{h}$ immersion time. It has been observed that both the surface analysis and EIS findings are very compatible with each other.

Keywords: Lavandula, EIS, $\mathrm{HCl}$ corrosion, Green inhibitor, SEM.
Lavanta türü özütünün hidroklorik asit çözeltisindeki yumuşak çelik korozyonunu etkin önlemesindeki rolü

öz

$\mathrm{Bu}$ çalışmadaki lavanta özütünün rolü, yeşil ve çevre dostu etkisi ile ortam koşullarındaki yumuşak çeliğin korozyonunu önleme etkisini incelemektir. İnhibitörün etkisi, elektrokimyasal impedans spektroskopisi (EIS) kullanılarak farklı daldırma sürelerinde belirlenmiştir. $\mathrm{Bu}$ ölçüm sonuçlarından, $\mathrm{HCl}$ çözeltisi içerisindeki lavanta ekstraktının derişimi arttıkça, EIS diyagramındaki polarizasyon direnci $\left(R_{p}\right)$ değerlerinin de arttığı gözükmüştür. Son olarak, en yüksek derişimde $(\% 0.500(\mathrm{w} / \mathrm{v}))$ lavanta özütü içeren elektrodun, 120 saat daldırma süresi sonundaki yüzey inhibisyonunu daha iyi açıklamak için taramalı elektron mikroskobu (SEM) analizi yapılmıştır. Hem yüzey analizlerinin hem de EIS bulgularının birbiriyle son derece uyumlu oldukları görülmüştür.

Anahtar Kelimeler: Lavanta, EIS, HCl korozyonu, Yeşil inhibitör, SEM.

and aqueous. For this reason, it is essential to use it in scientific corrosion research.

There are many corrosion protection methods available. Among these, the most effective and widely used one is inhibitor application. Both inorganic and organic compounds are used effectively as inhibitors. However, there may be harmful effects on the environment. Recently, the use of plant extracts for corrosion inhibition and control purposes, especially as "green inhibitors", has attracted attention. ${ }^{4-8}$ One of the important sources of environmentally friendly inhibitors is plants. ${ }^{9}$ Extracts from bark, seeds, leaves, fruits and plant roots have been shown to contain mixtures of organic compounds containing $\mathrm{N}, \mathrm{S}$ and $\mathrm{O}$ atoms in its chemical formula, 
which are effectual inhibition on metal corrosion in aggressive solutions. ${ }^{10,11}$ Plant extracts are extremely abundant resources of chemical compounds such as organic acids, amino, terpenoids, alkaloids, tannins and phenolic compounds that are naturally found and synthesized in the body, and many of them are known to have inhibitor effects. ${ }^{12-15}$ Lavandula extract/oil is extensively used in the fragrance and the pharmaceutical industry and, more recently, in food production as a natural sweetener for ice cream, candies and beverages. Literature researches reveal that no study has been conducted on the inhibition performance of Lavandula extract on the corrosion of mild steel involved in this study.

Apart from some extracts, the extracts from the leaves were generally those that indicated understandably better preservation at comparatively low concentrations. The reason for this has been pointed out that leaves are the main resource of phytochemicals. ${ }^{16,17}$ Extracts can be classified in two ways: aqueous medium or organic solvent. Extracts from both media are selected according to the areas to be applied. For example, in corrosion studies, it is preferred to use extracts obtained from an aqueous medium, since the conditions are generally carried out in an aqueous electrolyte solution. In general, aqueous solution extracts include polar phytochemicals, while organic solution extracts include non-polar phytochemicals. $^{18,19}$ Phytochemicals carrying polar groups such as amine $\left(-\mathrm{NH}_{2}\right)$, hydroxyl $(-\mathrm{OH})$, ester (COOR), carboxylic acid (-COOH), acetyl chloride ($\mathrm{COCl})$ and amide $\left(-\mathrm{CONH}_{2}\right)$ are the main elements that provide adsorption to the metal surface as corrosion inhibitors. There are some basic groups in phytochemicals that provide corrosion inhibition. The most important of these are: Glycosides, alkaloids, flavonoids, steroids, tannins, phytosterols, flobatannins, anthraquinones, amino acids, triterpenes and phenolic compounds. ${ }^{20,21}$ Due to their biological origin, plant extracts are environmentally friendly and often exhibit high preservation efficiency even at much lower concentrations.

Plants are unparalleled beings that transform the solar energy into a resource of living via photosynthesis. The lavender plant has a wide range of uses. The fresh flowered branch tips of lavender are generally used in the perfume industry, while the dried flower and leaf parts are used in the cosmetics industry. It is a shrub-looking perennial plant. Lavender can be sized between 20 and $60 \mathrm{~cm}$. In this study, the extract of "Lavandula sp." from Lamiaceae family was used and its inhibitor influence was examined. It is also especially significant study in terms of inhibiting the corrosion of the mild steel electrode in $\mathrm{HCl}$ solution. It was intended to examine the influence of the Lavandula extract as an inhibitor on the mild steel corrosion in hydrochloric acid solution by EIS experiments in different immersion periods with various concentrations. As result, it has been argued that the nontoxic and eco-friendly Lavandula extract is a highly effective inhibitor for industrial applications.

\section{MATERIALS AND METHODS}

\subsection{Plant material}

Lavenders used in the study were was collected from Niğde-Bor, Bereket village, $37^{\circ} 43^{\prime} 50^{\prime \prime} \mathrm{N}, 34^{\circ} 32^{\prime} 35^{\prime \prime} \mathrm{E}$, in July 2020.

\subsection{The solutions of Lavandula extract}

Chemicals used in electrochemical tests are of analytical grade. Lavandula samples were firstly dried in an oven for almost 1 hour at $80^{\circ} \mathrm{C}$ for preparing the stock solution of this plant's flowers extract. The flowers of the plant dried were separated from their stems. Dried $10 \mathrm{~g}$ of the violet flowers samples were weighed (Figure 1) and was added in $250 \mathrm{~mL}$ distilled water and refluxed for $18 \mathrm{~h}$.

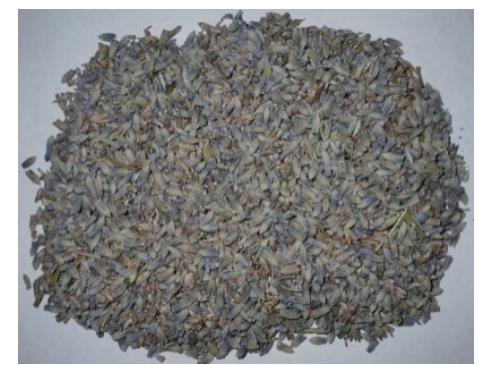

Figure 1. Dried violet Lavandula specimens.

The refluxed solution was filtered. Photographs of the filtration and clear extract obtaining steps are presented in Figure 2.
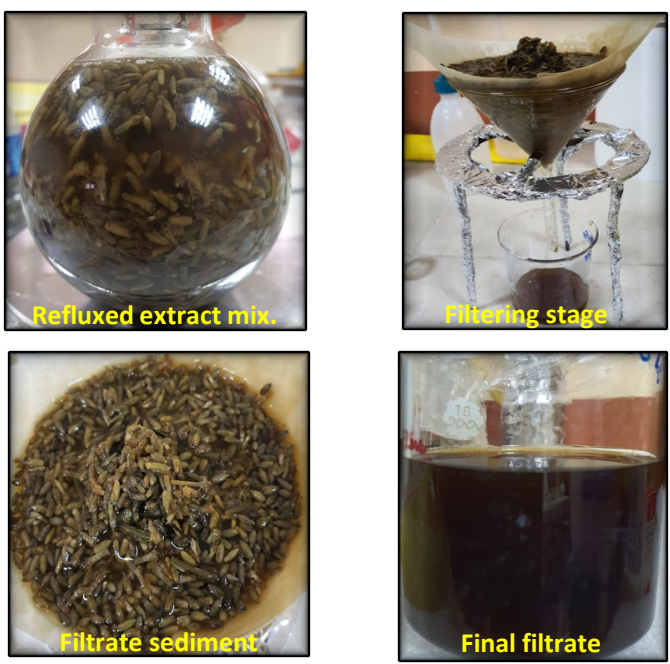

Figure 2. Extract acquisition stages. 
The concentration of the stock Lavandula solution studied was $1.376 \%(\mathrm{w} / \mathrm{v})$. All solution concentrations were diluted from the stock Lavandula solution. Electrochemical experiments were performed in $1.0 \mathrm{M}$ $\mathrm{HCl}$ solution for aggressive media.

\subsection{Electrodes and EIS measurements}

The electrochemical tests were obtained on the surface of mild steel electrodes. The chemical composition (wt.\%) of working electrodes is given in Table 1 .

Table 1. The chemical composition of the working electrodes samples.

\begin{tabular}{|cccccc|}
\hline Element & $\%$ & Element & $\%$ & Element & $\%$ \\
\hline $\mathbf{( C )}$ & 0.08400 & $\mathbf{( S i )}$ & 0.10200 & $\mathbf{( M n )}$ & 0.40900 \\
$\mathbf{( P )}$ & 0.01100 & $\mathbf{( S )}$ & 0.01900 & $\mathbf{( C r )}$ & 0.06030 \\
$\mathbf{( M o )}$ & 0.01040 & $\mathbf{( N i )}$ & 0.07890 & $\mathbf{( A l )}$ & Trace \\
$\mathbf{( C o )}$ & 0.00198 & $\mathbf{( C u )}$ & 0.21700 & $\mathbf{( N b )}$ & 0.00222 \\
$\mathbf{( T i )}$ & Trace & $\mathbf{( V )}$ & 0.01100 & $\mathbf{( W )}$ & Trace \\
$\mathbf{( P b )}$ & Trace & $\mathbf{( S n )}$ & 0.01620 & $\mathbf{( S b )}$ & Trace \\
$\mathbf{( F e )}$ & Remain & & & & \\
\hline
\end{tabular}

The electrodes were placed in a mould including polyester mixture and a surface area of $0.5024 \mathrm{~cm}^{2}$ of the electrodes was subjected to hydrochloric acid solution. The surfaces of the test electrodes were abraded with 150 , 600 and 1000 grids of sandpaper and polished and cleaned with alumina solution and acetone, respectively before each electrochemical experiment. The conventional three electrode methods were applied for EIS experiments. The first electrode is the working electrode and mild steel is used. The second is the counter electrode and a Pt plate with a surface area of $1.0 \mathrm{~cm}^{2}$ is used. The third and last electrode is the reference electrode and $\mathrm{Ag} / \mathrm{AgCl}$ has been used for this. All potentials in the study were measured against this $\mathrm{Ag} / \mathrm{AgCl}$ electrode.

EIS experiments were studied utilizing CHI 660B electrochemical analyser with a computer-controlled (Fig. 3).

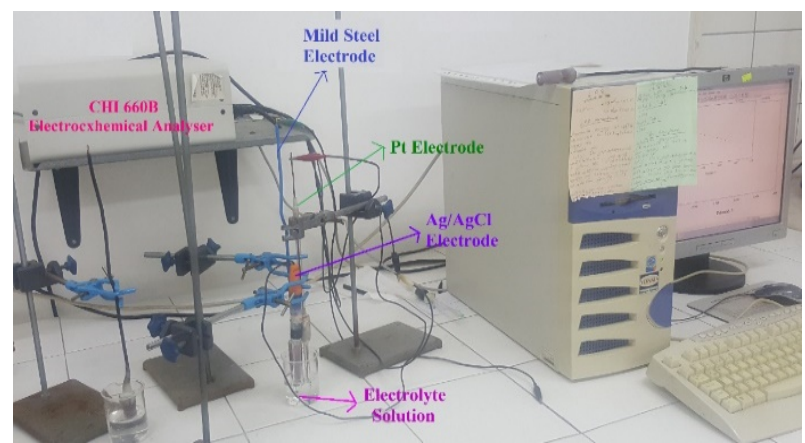

Figure 3. Photo of the experimental setup of a corrosion measurement with electrochemical analyser device in a laboratory area.
EIS measurements were performed in 1.0 M hydrochloric acid solution in with and without different Lavandula extract concentrations. The mild steel specimens were immersed in electrolyte solution for $1 \mathrm{~h}$ to equilibrate the corrosion potential $\left(E_{\text {corr }}\right)$ at the corrosion process prior to each EIS experiments. It was obtained on the corrosion potential at a frequency range of $10^{5}$ to $5 \times 10^{-3} \mathrm{~Hz}$ with 5 $\mathrm{mV}$ amplitude carried out by EIS. One, 24 and $120 \mathrm{~h}$ experiments were performed to investigate immersion time EIS periods and it was compared that the inhibition efficiency values obtained by EIS at different exposure times. SEM (Zeiss SEM 500 with computer controlled) images were performed $120 \mathrm{~h}$ of immersion time in hydrochloric acid solution with and without Lavandula sp. extract at the highest concentration $(0.500 \%)$. All experiments were realized at ambient temperature (298 $\mathrm{K})$.

\section{RESULTS and DISCUSSION}

\subsection{Evaluation of EIS findings}

Impedance spectroscopy is one of the fastest and easiest methods that are often preferred in researching the protective properties of all these molecules on metals in aggressive solutions, whether the inhibitor used is organic molecules or inhibitors of plant origin. ${ }^{22-24}$ For this reason, electrochemical behaviour of mild steel was evaluated by measuring with EIS at the end of one, 24 and $120 \mathrm{~h}$ immersion times in $1.0 \mathrm{M} \mathrm{HCl}$ solutions containing four different concentrations of Lavandula $(0.100 \%, 0.050 \%, 0.300 \%$ and $0.500 \%(\mathrm{w} / \mathrm{v}))$ and not containing inhibitor. The equivalent circuits of the corrosion process were constituted from these results by utilizing Zview2 software. The EIS parameters concerned to the corrosion process are also given in Table 2.

Table 2. The related data acquired from fitting EIS measurements for mild steel in acidic solution with Lavandula extract at various exposure time.

\begin{tabular}{|c|c|c|c|c|c|c|c|}
\hline \multirow{2}{*}{$\underset{(\mathrm{w} / \mathrm{v} \%}{\mathrm{C} \%}$} & \multirow[b]{2}{*}{$\begin{array}{c}\boldsymbol{R}_{\boldsymbol{s}} \\
\left(\Omega \mathrm{cm}^{2}\right)\end{array}$} & \multirow[b]{2}{*}{$\begin{array}{c}R_{p} \\
\left(\Omega \mathrm{cm}^{2}\right)\end{array}$} & \multicolumn{2}{|c|}{ CPE } & \multirow[b]{2}{*}{$\begin{array}{c}R_{L} \\
\left(\Omega \mathrm{cm}^{2}\right)\end{array}$} & \multirow[b]{2}{*}{$\begin{array}{c}L \\
\text { (H) }\end{array}$} & \multirow[b]{2}{*}{$\begin{array}{c}\eta \\
(\%)\end{array}$} \\
\hline & & & $\left.(\mu \mathrm{F} \mathrm{cm})^{-2}\right)$ & $n$ & & & \\
\hline $1 \mathrm{~h}$ & & & & & & & \\
\hline Blank & 1.2 & 72 & 110 & 0.94 & 8 & 4 & - \\
\hline 0.050 & 1.2 & 320 & 106 & 0.89 & - & - & 77.5 \\
\hline 0.100 & 1.3 & 540 & 83 & 0.86 & - & - & 86.7 \\
\hline 0.300 & 1.2 & 750 & 78 & 0.84 & - & - & 90.4 \\
\hline 0.500 & 1.3 & 805 & 73 & 0.83 & - & - & 91.1 \\
\hline $24 \mathrm{~h}$ & & & & & & & \\
\hline Blank & 1.2 & 11 & 2600 & 0.95 & 1.3 & 1.1 & - \\
\hline 0.050 & 1.5 & 170 & 310 & 0.85 & - & - & 93.5 \\
\hline 0.100 & 1.3 & 470 & 110 & 0.84 & - & - & 97.8 \\
\hline 0.300 & 1.3 & 600 & 90 & 0.84 & - & - & 98.2 \\
\hline 0.500 & 1.1 & 674 & 80 & 0.83 & - & - & 98.4 \\
\hline $120 \mathrm{~h}$ & & & & & & & \\
\hline Blank & 1.4 & 4 & 36520 & 0.89 & 0.4 & 0.3 & - \\
\hline 0.050 & 1.6 & 50 & 1647 & 0.83 & - & - & 92.0 \\
\hline 0.100 & 1.1 & 186 & 360 & 0.60 & - & - & 97.9 \\
\hline 0.300 & 1.1 & 251 & 290 & 0.48 & - & - & 98.4 \\
\hline 0.500 & 1.1 & 486 & 274 & 0.35 & - & - & 99.2 \\
\hline
\end{tabular}


Proposed equivalent electrical circuits for mild steel electrodes were inserted in Figure 4 and the Nyquist diagrams in $\mathrm{HCl}$ solution of the extract have been showed for different exposure time in Figure 4.
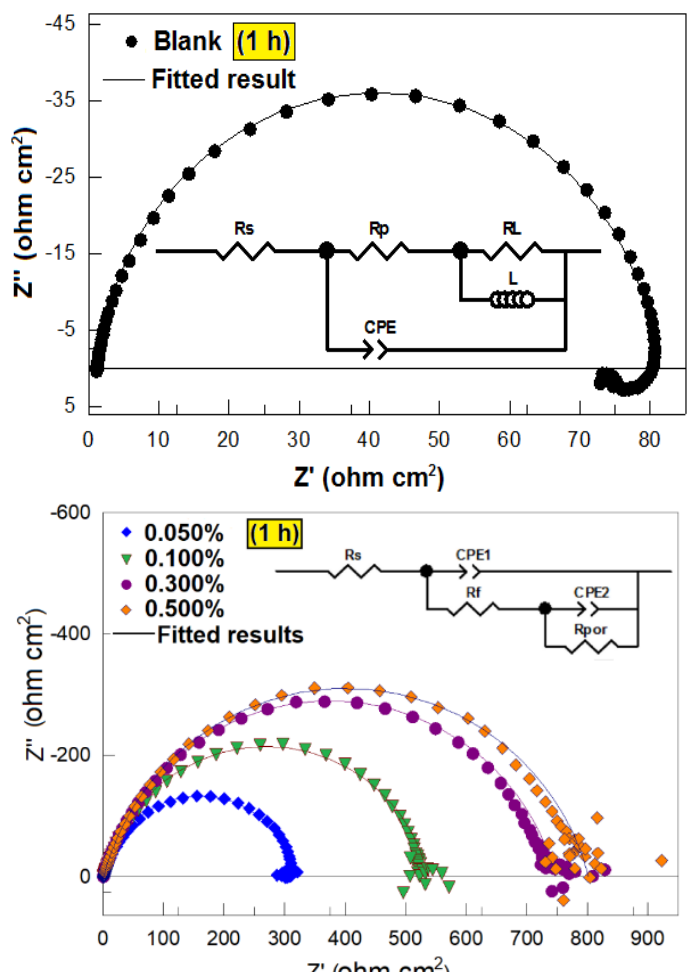

Z' (ohm cm²)
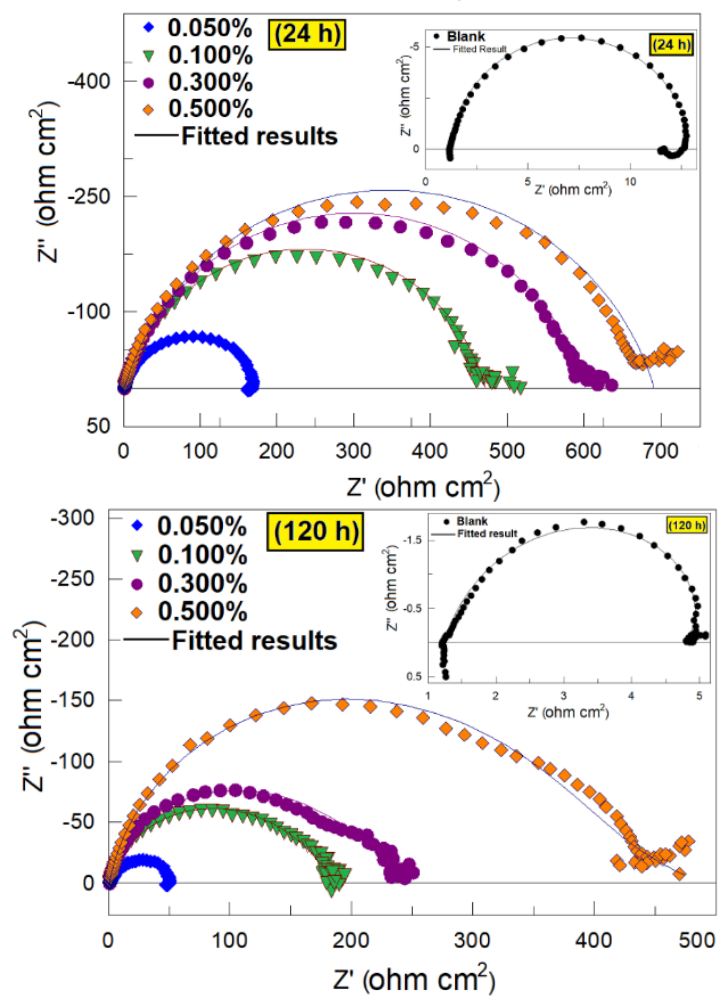

Figure 4. Fitted impedance curves for mild steel specimens in hydrochloric acid with and without various Lavandula extract concentrations for 1,24 and $120 \mathrm{~h}$
In the EIS diagram obtained for $1 \mathrm{~h}$ immersion period in Figure 4, it is viewed that the equivalent circuit model proposed for the inhibited solution is distinct from the one proposed for the uninhibited solution. One of the most obvious differences between the two is the adsorption film layer that comes into play in the inhibited solution. As can be clearly seen from Figure 4, the radii of the semicircles composed in the high frequency area in all inhibited solutions were greater than those in uninhibited ones, and the radii enhanced as the concentration of inhibitor enhanced. ${ }^{25-28}$

The " $n$ " values shown in Table 2 are the surface roughness coefficient of the metal. As Lavandula extract solutions were added to the blank solution, the " $n$ " values decreased, in other words, the surface roughness gradually diminished. " $R_{p}$ " is the polarization resistance, that is, the molecules of Lavandula extract are polarized by adsorption to the metallic surface in a corrosion process. While the $R_{p}$ value in the blank solution was 72 $\Omega \mathrm{cm}^{2}$, as Lavandula was added to the medium at the last of each immersion period, the $R_{p}$ values increased. In addition, as the exposure period to the acidic solution increased, the $R_{p}$ values at each concentration gradually decreased as the corrosion process continued. Percent inhibition efficiency values $(\eta \%)$ calculated from $R_{p}$ values at the end of one-hour immersion time increased as Lavandula extract was added to the acidic solution, and this value provided a high inhibition rate of $91.1 \%$ at the highest Lavandula concentration $(0.500 \%)$.

Another impedance parameter in Table 2 is the "CPE" value. $C P E$ is the "constant phase element" in the electrical equivalent circuit and is conversely proportional to the $R_{p}$ value. $^{29}$ As the extract concentration increases in the solution medium, the $C P E$ value decreases accordingly. In the EIS diagrams obtained in solutions containing Lavandula during each immersion period, it is viewed that the diameter of the capacitive loop increases significantly with the increase of the concentration. As can be seen in the Nyquist curve of the $120 \mathrm{~h}$ immersion time, where the exposure time to the acidic solution was the highest, the capacitive curves were gradually distorted. As a result of all these parameters and high inhibition values, it can be commented that as the concentration increases, the protective inhibitor film formed on the surface grows and the metal surface is well closed.

From all EIS diagrams, as the electrodes are exposed to acidic solutions, deviations from the semicircles, in other words frequency scattering, are clearly observed in the EIS plots. These scattering is actually caused by the increase of roughness on the metal surface due to prolonged exposure to the acidic solution. Among the 
causes of high inhibition, which is also common in green type inhibitors, but involves almost all inhibitors, is the processes that occur in the high and low frequency regions of the Nyquist curves. Diffuse layer resistance $\left(R_{d}\right)$ and charge transfer resistance $\left(R_{c t}\right)$ play a role in the inhibition in the high frequency part, on the other hand, in the low frequency area, the film resistance $\left(R_{f}\right)$ in control of the film layer composed on the surface and all accumulated resistances $\left(R_{a}\right)$ that are present with corrosion products on the metal surface generally play a dominant role in a corrosion process. ${ }^{30}$

It can be said that percentages of inhibition in Table 2 are around $90 \%$ and above, except for a few values. In addition, the highest inhibition (99.2\%) was obtained at the end of $120 \mathrm{~h}$ with the solution containing the highest amount of Lavandula extract. As can be seen from the results, it is possible to say that Lavandula molecules adsorb very well on the mild steel surface and cover the surface almost completely. Plant extracts called green usually involve complex secondary metabolites (phytochemicals) that can polarize certain functional groups and double bonds in their structures. ${ }^{31,32}$ These functional groups and double bonds are regions rich in electron. For this reason, these parts, which are rich electron sources, facilitate the adsorption of phytochemical-containing plant extracts to the metal surface. Phytochemicals are natural and at the same time therapeutic compounds synthesized in plants as secondary metabolites. Its high inhibition effect on corrosion is caused by secondary metabolites (phytochemicals) well-known to include molecules such as nitrogenous compounds, phenolic compounds, flavonoids, terpenes and alkaloids. All of these compounds are also quite a source of $\pi$-electrons.

\subsection{Evaluation of SEM images of mild steel electrodes}

Present study investigating the effect of Lavandula extract on the surface of mild steel was carried out by examining the surface micrographs obtained by SEM technique. In the first stage, the mild steel electrodes were removed from the immersed solutions for $120 \mathrm{~h}$, cleaned and dried. Afterwards, the SEM images obtained by cutting of $0.5 \mathrm{~cm}$ from the electrode surface with a hacksaw without waiting are given in Figure 5.

As can be easily seen from these surface micrographs, large black cavities in the form of recessions and pits are clearly monitored on the electrode surface kept in the blank solution. It can be said that the image of immersed in the blank solution is clearly oxidized and the surface is deteriorated. It is observed that the metal surface has a much smoother appearance, and the black cavities (pits) are almost absent with the Lavandula extract added to the acidic solution. In other words, it can be clearly emphasized that the electrode surfaces are the roughest in the blank solution, the black spots are quite large and numerous, and they have the smoothest appearance at the highest concentration. ${ }^{33}$ These results highly confirm each other with the long-term impedance results obtained with EIS.
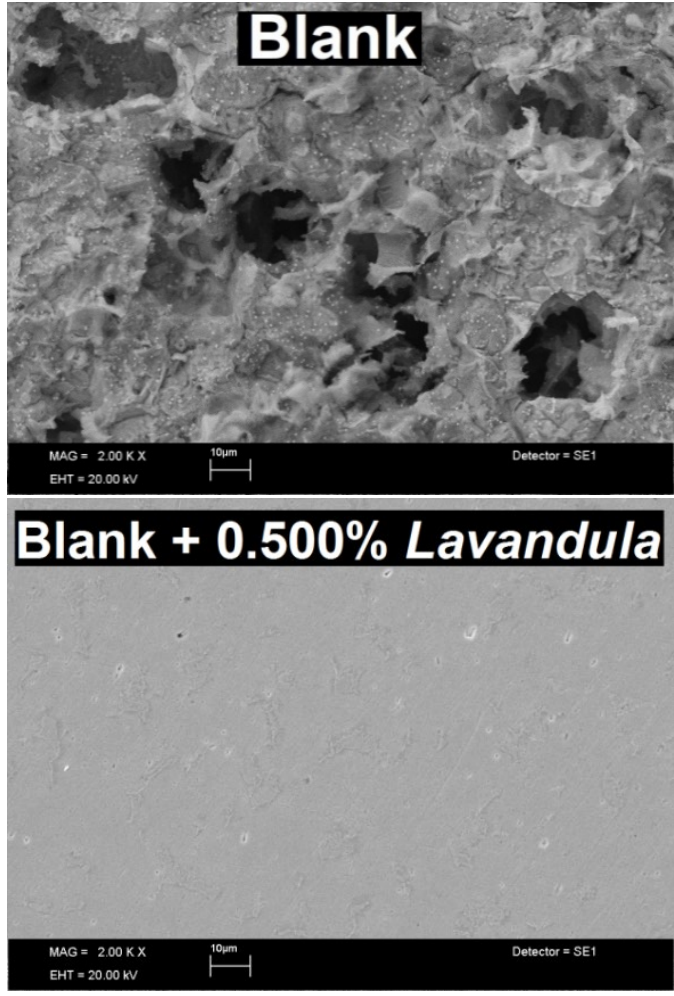

Figure 5. SEM images of electrodes immersed in hydrochloric acid solution for $120 \mathrm{~h}$.

These results indicate high inhibition as a result of the Lavandula extract covering the surface of mild steel very well, and at the same time, the smoother the surface with the addition of the extract can be shown as another proof that it provides a very good inhibition.

\section{CONCLUSIONS}

In this current study conducted to define the electrochemical behavior of mild steel, experiments were made with EIS at last of one, 24 and $120 \mathrm{~h}$ of immersion in uninhibited and inhibited solutions and the results are summarized below:

- Lavandula extract, which is green and environmentally friendly, is intended to be used as an inhibitor for application at different immersion times against the mild steel corrosion in aggressive $\mathrm{HCl}$ solution and as a result, it has shown a very high inhibition performance. 
- The impedance diagrams obtained at three different immersion times in both blank and inhibited solutions are in the form of a half ellipse. The radii of the semicircles in all inhibitor solutions are greater than those in the blank solution, and the radii enhanced as the inhibitor concentration raised.

- As the exposure time enhanced in inhibited solutions, the diameter of the capacitive loop decreased. In both non-inhibitor and inhibitor solutions, CPE values raised with enhancing immersion time and decreased with raising the concentration of Lavandula extract.

- Due to the increment in the inhibitor concentration, as the immersion time increased, the values of "the surface roughness coefficient: $n$ " decreased, which can be interpreted as evidence of the adsorption of Lavandula extract molecules on the metallic surface.

- After one, 24 and $120 \mathrm{~h}$ exposure times of the mild steel electrodes to the acidic solution, the inhibition performance for Lavandula extract was approximately between $78 \%$ and $99 \%$. This ratio is quite high and this has been suggested as evidence that the number of molecules in the Lavandula extract adsorbed on the mild steel surface increases due to the increment in Lavandula extract concentration.

- In the last stage of the study, the effect of Lavandula extract on the mild steel/solution interface was investigated using the SEM technique. On the electrode surface, which was kept in the acidic blank solution for $120 \mathrm{~h}$, quite large and deep cavities (pits) were observed. On the contrary, when there is Lavandula extract in the acidic solution, it is very clear that these formed pits disappear or even become smaller. In other words, it was determined that the electrode surface in the blank solution was the roughest and the metal surface in the solution containing the Lavandula extract was the smoothest.

- SEM and EIS findings were also very compatible with each other.

- In the light of the results of this study, a plant extract called green inhibitor is a very useful and suitable inhibitor for the mild steel electrode in 1.0 $\mathrm{M}$ hydrochloric acid, moreover, it was concluded that such inhibitors should be encouraged to increase their use because they are environmentally friendly and do not show toxic effects.

\section{Conflict of interest}

Author declares that there is no a conflict of interest with any person, institute, company, etc.

\section{REFERENCES}

1. Şahin, M.; Çadırlı, E.; Sürme, Y.; Özkır, D. ThermoElectrical Properties in $\mathrm{Pb}-\mathrm{Sb}$ Hypereutectic Alloy, Met. Mater. Int. 2013, 19(3), 465-472.

2. Berrissoul A., Ouarhach A., Benhiba F., Romane A., Zarrouk A., Guenbour A., Dikici B., Dafali A., Evaluation of Lavandula mairei extract as green inhibitor for mild steel corrosion in $1 \mathrm{M} \mathrm{HCl}$ solution. Experimental and theoretical approach, J. Mol. Liq. 2020, 313, 113493.

3. Loto C.A., Loto R.T., Effects of Lavandula and Ricinus Communis Oil as Inhibitors of Mild Steel Corrosion in HCL and $\mathrm{H}_{2} \mathrm{SO}_{4}$ Media, Procedia Manuf. 2019, 35, 407-412.

4. Loto C.A., Synergism of Saccharum Officinarum and Ananas Comusus Extract Additives on the Quality of Electroplated Zinc on Mild Steel, Res. Chem. Intermed. 2014, 40, 1799-1813.

5. Aljuhani A., El-Sayed W.S., Sahu P.K., Rezki N., Aouad M.R., Salghi R., Messali M., Microwave-assisted synthesis of novel imidazolium, pyridinium and pyridazinium based ionic liquids and/or salts and prediction of physicochemical properties for their toxicity and antibacterial activity, J. Mol. Liq. 2018, 249 , 747-753.

6. Ameta G., Pathak A.K., Ameta C., Ameta R., Punjabi P.B., Sonochemical synthesis and characterization of imidazolium based ionic liquids: a green pathway, $J$. Mol. Liq. 2015, 211, 934-937.

7. Abdel-Gaber A.M., Abd-El-Nabey B.A., Sidahmed I.M., El-Zayady A.M., Saadawy M., Inhibitive action of some plant extracts on the corrosion of steel in acidic media. Corros. Sci. 2006, 48, 2765-2779.

8. Alibakhshi E., Ramezanzadeh M., Bahlakeh G., Ramezanzadeh B., Mahdavian M., Motamedi M., Glycyrrhiza glabra leaves extract as a green corrosion inhibitor for mild steel in $1 \mathrm{M}$ hydrochloric acid solution: experimental, molecular dynamics, Monte Carlo and 
quantum mechanics study, J. Mol. Liq. 2018, 255, 185198.

9. Benabbouha T., Siniti M., El Attari H., Chefira K., Chibi F., Nmila R., Rchid H., Red algae Halopitys incurvus extract as a green corrosion inhibitor of carbon steel in hydrochloric acid, J. Bio. Tribocorros. 2018, 4 (39), 1-9.

10. Odewunmi N.A., Umoren S.A., Gasem Z.M., Watermelon waste products as green corrosion inhibitors for mild steel in $\mathrm{HCl}$ solution, J. Environ. Chem. Eng. 2015, 3, 286-296.

11. Mourya P., Banerjee S., Singh M.M., Corrosion inhibition of mild steel in acidic solution by Tagetes erecta (Marigold flower) extract as a green inhibitor, Corros. Sci. 2014, 85, 352-363.

12. Halambek J., Berkovic' K., Vorkapić-Furač J., The influence of Lavandula angustifolia L. oil on corrosion of Al-3Mg alloy, Corros. Sci. 2010, 52, 3978-3983.

13. Abiola O.K., James A.O., The effects of Aloe vera extract on corrosion and kinetics of corrosion process of zinc in $\mathrm{HCl}$ solution, Corros. Sci. 2010, 52, 661-664.

14. Abdel-Gaber A.M., Khamis E., Abo-ElDahab H., Adeel S., Inhibition of aluminium corrosion in alkaline solutions using natural compound, Mater. Chem. Phys. 2008, 109, 297-305.

15.Zerga B., Sfaira M., Rais Z., Touhami M.E., Taleb M., Hammouti B., Imelouane B., Elbachiri A., Lavender oil as an ecofriendly inhibitor for mild steel in $1 \mathrm{M} \mathrm{HCl}$, Mater. et Tech. 2009, 97, 297-305.

16. Schreiner M., Huyskens-Keil S., Phytochemicals in fruit and vegetables: health promotion and postharvest elicitors, Crit. Rev. Plant Sci. 2006, 25, 267-278.

17. Alrefaee S.H., Rhee K.Y., Verma C., Quraishi M.A., Ebenso E.E., Challenges and advantages of using plant extract as inhibitors in modern corrosion inhibition systems: Recent advancements, J. Mol. Liq. 2021, 321, 114666.

18. Ji G., Shukla S.K., Dwivedi P., Sundaram S., Prakash R., Inhibitive effect of Argemone mexicana plant extract on acid corrosion of mild steel, Ind. Eng. Chem. Res. 2011, 50, 11954-11959.

19. Krishnegowda P.M., Venkatesha V.T., Krishnegowda P.K.M., Shivayogiraju S.B., Acalypha torta leaf extract as green corrosion inhibitor for mild steel in hydrochloric acid solution, Ind. Eng. Chem. Res. 2013, 52, 722-728.

20. Raja P.B., Fadaeinasab M., Qureshi A.K., Rahim A.A., Osman H., Litaudon M., Awang K., Evaluation of green corrosion inhibition by alkaloid extracts of Ochrosia oppositifolia and isoreserpiline against mild steel in $1 \mathrm{M} \mathrm{HCl}$ medium, Ind. Eng. Chem. Res. 2013, 52, 10582-10593.

21. Oguzie E.E., Oguzie K.L., Akalezi C.O., Udeze I.O., Ogbulie J.N., Njoku V.O., Natural products for materials protection: Corrosion and microbial growth inhibition using Capsicum frutescens biomass extracts, $A C S$ Sustain. Chem. Eng. 2013, 1, 214-225.

22. Özkır, D. The Electrochemical Variation of a Kind of Protein Staining and Food Dye as a New Corrosion Inhibitor on Mild Steel in Acidic Medium. Int. J. Electrochem. 2019, 2019, 1-11.

23. Özkır, D. A Newly Synthesized Schiff Base Derived from Condensation Reaction of 2,5-dichloroaniline and benzaldehyde: Its Applicability through Molecular Interaction on Mild Steel as an Acidic Corrosion Inhibitor by Using Electrochemical Techniques. $J$. Electrochem. Sci. Technol. 2019, 10(1), 37-54.

24. Özkır, D.; Ezer, T. A New Inhibitor Approach to the Corrosion of Mild Steel in Acidic Solution with LongTerm Impedance Tests: A New Application Area for Hypnum cupressiforme (Bryophyta), Anatolian Bryology, 2020, 6(2), 119-128.

25. Sürme, Y.; Gürten, A.A. Role of polyethylene glycol tert-octylphenyl ether on corrosion behaviour of mild steel in acidic solution, Corros. Eng. Sci. Techn. 2009, 44(4), 304-311.

26. Özkır, D; Kayakırılmaz, K. The Inhibitor Effect of (E)-5-[(4-(benzyl(methyl)amino)phenyl)diazenyl]-1,4dimethyl-1H-1,2,4-triazol-4-ium zinc(II) Chloride, an Industrial Cationic Azo Dye, onto Reducing Acidic Corrosion Rate of Mild Steel, J. Electrochem. Sci. Technol. 2020, 11(3), 257-272.

27. Özkır, D.; Bayol, E.; Gürten, A.A.; Sürme, Y., Kandemirli, F. Effect of hyamine on electrochemical behaviour of brass alloy in $\mathrm{HNO}_{3}$ solution, Chem. Pap. 2013, 67(2), 202-212.

28. Kılınççeker, G.; Baş, M.; Zarifi, F.; Sayın, K. Experimental and Computational Investigation for (E)-2hydroxy-5-(2- benzylidene) Aminobenzoic Acid Schiff Base as a Corrosion Inhibitor for Copper in Acidic 
Media, Iran. J. Sci. Technol. Trans. Sci. 2021, 45, 515527.

29. Ongun Yüce, A.; Telli, E.; Doğru Mert, B.; Kardaş, G.; Yazıc1, B. Experimental and quantum chemical studies on corrosion inhibitioneffect of 5,5 diphenyl 2thiohydantoin on mild steel in $\mathrm{HCl}$ solution, J. Mol. Liq. 2016, 218, 384-392.

30. Yildiz, R.; Dogru Mert, B. Theoretical and experimental investigations on corrosion control of mild steel in hydrochloric acid solution by 4-aminothiophenol, Anti-Corros. Method. M. 2019, 66(1),127-137.

31. Palaniappan, N.; Cole, I.; Caballero-Briones, F.; Manickam, S.; Thomas, K.J.; Santos, D. Experimental and DFT studies on the ultrasonic energy-assisted extraction of the phytochemicals of Catharanthus roseus as green corrosion inhibitors for mild steel in $\mathrm{NaCl}$ medium, $R S C A d v$. 2020, 10, 5399-5411.

32. Buchweishaija J. Phytochemicals as green corrosion inhibitors in various corrosive media: A review, Tanz. J. Sci. 2009, 35, 77-92.

33. Keleş, H.; Keleş, M.; Sayın, K. Experimental and theoretical investigation of inhibition behavior of 2-((4(dimethylamino)benzylidene)amino)benzenethiol for carbon steel in $\mathrm{HCl}$ solution, Corros. Sci. 2021, 184, 109376. 